\title{
Pengaruh Pemberian Tablet Effervescent Mawar Merah (Rosa damascena Mill.) terhadap Kadar Ureum Darah Tikus Putih (Rattus norvegicus) Galur Wistar yang Diinduksi Karbon Tetraklorida $\left(\mathrm{CCl}_{4}\right)$
}

\author{
Nurdiana*® ${ }^{\star 凶}$ Aulia Chaya Kusuma*
}

\begin{abstract}
ABSTRAK
Karbontetraklorida adalah senyawa kimia organik volatil, yang dapat menyebabkan kerusakan jaringan, terutama pada hati dan ginjal.Telah diketahui pula bahwa antosianin pada bunga mawar merah memiliki sifat antioksidan. Tujuan penelitian ini untuk mengetahui pengaruh tablet effervescent mawar merah (Rosa damascenaMill.) terhadap kadar ureum darah tikus putih galur wistar (Rattus norvegicus) yang diinduksi oleh $\mathrm{CCl}_{4}$ sebagai penyebab stres oksidatif. Penelitian ini merupakan studi eksperimental laboratorium in vivo pada hewan coba tikus Wistar denganpost test only control group design. Hewan coba yang digunakan adalah tikus jantan galur Wistar $(\mathrm{n}=25)$, dan kerusakan ginjal pada tikus dinnduksi dengan pemberian $\mathrm{CCl}_{4}$ secara intraperitoneal dengan dosis $0,36 \mathrm{ml} / 136 \mathrm{gBB} / 3$ hari. Tablet effervescent sebagai antioksidan $(1,25$ $\mathrm{mg}, 2,5 \mathrm{mg}, 5 \mathrm{mg}$ ) diberikan melalui oral selama 14 hari. Hasil penelitian menunjukkan bahwa $\mathrm{CCl}_{4}$ dapat menyebabkan peningkatan kadar ureum secara signifikan pada kelompok kontrol positif. Peningkatan ureum mengindikasikan adanya kerusakan pada ginjal tikus. Pemberian tablet effervescent dapat menurunkan kadar ureum darah tikus secara signifikan $(p<0,05)$, sehingga dapat disimpulkan bahwa pemberian tablet effervescent mawar merah dapat melindungi ginjal dari stres oksidatif yang diakibatkan oleh $\mathrm{CCl}_{4}$.
\end{abstract}

Kata kunci: antosianin, $\mathrm{CCl}_{4}$, ureum darah, tablet effervescent, mawar merah.

\section{Effect of Effervescent Tablet from Red Rose (Rosa damascena Mill.) on Blood Ureum Level of Rat (Rattus norvegicus) Induced by Carbon Tetrachloride $\left(\mathrm{CCl}_{4}\right)$}

\begin{abstract}
Carbon tetrachloride is a volatile organic compound, which can cause tissue damage, especially to the liver and kidneys. It is known that anthocyanin have antioxidative properties. The aim of this study was to evaluate the effect of red rose effervescent tablet (Rosa damascena Mill.) treatment on $\mathrm{CCl}_{4}$-induced oxidative stres and nephrotoxicity in rats using blood ureum level as parameter. This study was an experimental laboratory with post-test only controlled group design. The study was employed male rats $(\mathrm{n}=25)$, and nephrotoxicity was induced by intraperitoneal injection of $\mathrm{CCl}_{4} 0.36 \mathrm{ml} / 136 \mathrm{~g} \mathrm{BW} / 3$ days. Rats were orally administered with the red rose effervescent tablet in many doses $(1.25 \mathrm{mg}, 2.5 \mathrm{mg}, 5 \mathrm{mg})$ for 14 days. The results showed that $\mathrm{CCl}_{4}$ caused significant increasing blood ureum level on positive control group. The pathological evaluation indicated the kidney was damage by $\mathrm{CCl}_{4}$. The red rose effervescent tablet decreased blood ureum level compared to positive control group $(p<0,05)$. Therefore, the red rose effervescent tablet can protect the kidney against $\mathrm{CCl}_{4}$
\end{abstract}

Keywords: anthocyan, blood ureum level,CCl 4 , effervescent tablet, red rose.

* Program Studi Pendidikan Dokter, FKUB

E-mail: farmakodes@gmail.com 


\section{PENDAHULUAN}

Ginjal adalah sepasang organ saluran kemih yang terletak di rongga retroperitoneal bagian atas. ${ }^{1}$ Fungsi utama ginjal adalah untuk membuang sisa-sisa metabolisme segera setelah tidak diperlukan lagi oleh tubuh. ${ }^{2}$ Ginjal melakukan fungsinya yang paling penting dengan cara menyaring plasma dan memisahkan zat dan filtrat dengan kecepatan yang bervariasi, bergantung kebutuhan tubuh. Besar kecepatan berbagai zat yang "dibersihkan" dari plasma merupakan cara yang berguna untuk menghitung efektivitas ginjal dalam mengeksresikan berbagai zat. Beberapa uji faal ginjal yang sering diperiksa adalah pemeriksaan klirens kreatinin, kreatinin dan

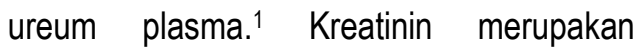
metabolit daricreatine phosphate, yang merupakan energi cadangan untuk regenerasi ATP dan ditemukan dalam jumlah besar di otot skelet dan hampir seluruhnya dibersihkan dari tubuh oleh filtrasi glomerulus. ${ }^{2}$

Tanpa disadari dalam tubuh kita terbentuk radikal bebas secara terus menerus. ${ }^{3}$ Tapi, tubuh juga mempunyai mekanisme yang dapat menetralisir bahaya radikal bebas dengan sistem antioksidan. Peningkatan produksi radikal bebas dan stres oksidatif dapat juga disebabkan oleh berbagai faktor seperti radiasi atau paparan logam berat dan xenobiotik. ${ }^{4} \mathrm{Hal}$ ini menyebabkan timbulnya berbagai macam penyakit dan gangguan pada organ-organ tubuh. ${ }^{5}$

Senyawa $\mathrm{CCl}_{4}$ diketahui sebagai bahan kimia yang dapat menyebabkan hepatotoksik dan nefrotoksik. $\mathrm{CCl}_{4}$ diaktifkan di hepar menjadi trichloromethyl $\left(\mathrm{CCl}_{3}{ }^{*}\right)$ dan radikal trichloromethyl peroxyl $\left(\mathrm{CCl}_{3} \mathrm{O}_{2}{ }^{*}\right)$ yang menginisiasi terjadinya peroksidasi lipid pada fosfolipid membran sel dan menyebabkan perubahan fungsional serta morfologi membran sel, menyebabkan akumulasi lipid-derived oxidant sehingga terjadi kerusakan hepar. ${ }^{6}$ Penelitian secara in vitro dan in vivo menyatakan bahwa $\mathrm{CCl}_{4}$ mempercepat peroksidasi lipid, mengurangi NADPH sitokrom P450 renal, dan mengurangi rasio glutation (GSH/GSSG) pada korteks ginjal seperti halnya pada mikrosomal dan mitokondria ginjal. ${ }^{7}$ Selanjutnya, jika terjadi kerusakan ginjal yang parah, maka akan terjadi kenaikan kreatinin serum, level BUN (blood urea nitrogen) dan penurunan klirens kreatinin dan ureum. ${ }^{8}$

Di era global, kehidupan dengan aktivitas fisik berat, serta pengaruh lingkungan akan menyebabkan radikal bebas sulit dihindari, sehingga perlu diusahakan untuk meningkatkan antioksidan di dalam tubuh. Salah satunya adalah pigmen antosianin yang terdapat dalam bunga mawar.

Bunga mawar merupakan flora yang tumbuh subur di Indonesia. Hasil penelitian terhadap bunga mawar yang segar maupun yang telah dipajang selama 4-6 hari, ekstraknya masih berpotensi digunakan sebagai zat pewarna sekaligus sebagai antioksidan. ${ }^{9}$ Kandungan senyawa antioksidan yang tinggi membuat potensi pigmen bunga mawar tidak hanya sebagai pewarna makanan, namun juga telah diolah menjadi tablet effervescent yang akhir-akhir ini digemari konsumen karena praktis, cepat disajikan dan dapat menjadi suplemen.

Berdasarkan penjelasan di atas maka perlu dilakukan studi lebih lanjut mengenai efektivitas tablet effervescent ekstrak mawar merah (Rosa damascena Mill.) untuk memproteksi ginjal dari radikal bebas yaitu $\mathrm{CCl}_{4}$ dengan melihat kadar kreatinin darah tikus putih (Rattus norvegicus) galur Wistar.

Tujuan penelitian ini adalah untuk mengetahui pemberian tablet effervescent ekstrak mawar merah (Rosa damascena 
Mill.) peroral mampu memberikan proteksi terhadap ginjal tikus putih (Rattus norvegicus) galur Wistar yang diinduksi karbon tetraklorida $\left(\mathrm{CCl}_{4}\right)$ dengan kadar ureum darah sebagai parameter. Manfaat yang diharapkan adalah untuk meningkatkan nilai guna dan nilai ekonomi dari bunga mawar merah (Rosa damascena Mill.) dan memberikan alternatif sebagai suplemen alami yang lebih menyehatkan.

\section{BAHAN DAN METODE}

\section{Waktu dan Tempat Penelitian}

Penelitian ini dilaksanakan dilakukan di Laboratorium Farmakologi FKUB dan laboratorium Kimia FKIP-UMM.

\section{Hewan Coba dan Kelompok Perlakuan}

Hewan coba yang digunakan untuk penelitian ini adah tikus putih jantan (Rattus norvegicus) galur Wistar yang sehat berumur 6-8 minggu sebanyak 25 ekor. Hewan coba dibagi dalam 5 kelompok perlakuan, yang masing-masing terdiri atas 5 ekor tikus. Penelitian dimulai dengan mengondisikan lingkungan awal bagi tikus selama 7 hari. Kemudian tikus dibagi menjadi kelompok kontrol dan kelompok perlakuan. Kelompok kontrol terdiri dari kontrol positif dan kontrol negatif.Kelompok kontrol negatif adalah kelompok tikus yang hanya diberi diet normal. Kelompok kontrol positif adalah kelompok tikus yang diberi diet normal dan induksi $\mathrm{CCl}_{4}$ dengan dosis $0,36 \mathrm{ml} / 136$
gBB/3 hari. Kelompok perlakuan adalah kelompok yang diberi proteksi tablet effervescent mawar merah lokal (Rosa damascena Mill.) dalam tiga dosis yaitu $\mathrm{P} 1$ $(1,25 \mathrm{mg})$, P2 $(2,5 \mathrm{mg})$, dan P3 $(5 \mathrm{mg})$ secara oral, lalu diinduksi $\mathrm{CCl}_{4}$ dengan dosis $0,36 \mathrm{ml} / 136 \mathrm{~g} \mathrm{BB} / 3$ hari. Perlakuan ini dilakukan selama 14 hari.

\section{Pemberian Tablet Effervescent}

Dosis tablet effervecent ekstrak mawar (Rosa damascena Mill.) yang diberikan secara oral pada kelompok perlakuan P1, $\mathrm{P} 2$, dan P3 yaitu berturut-turut $1,25 \mathrm{mg}, 2,5$ $\mathrm{mg}$, dan $5 \mathrm{mg}$.

\section{Pemberian Karbon Tetraklorida $\left(\mathrm{CCl}_{4}\right)$ \\ Sediaan $\mathrm{CCl}_{4}$ yang diberikan sebesar $0,18 \mathrm{ml} / 136 \mathrm{gBB} / 3$ hari yang dilakukan secara subkutan menggunakan spuit.}

\section{Kadar Ureum}

Kadar ureum adalah jumlah zat sisa metabolisme yang terdapat dalam serum darah yang diukur dengan metode spektofotometri.

\section{Analisis Data}

Hasil data dianalisis secara statistik dengan taraf keprcayaan 95\% ( $\alpha=0,05)$. Metode analisis data menggunakan uji oneway ANOVA dan dilanjutkan dengan uji LSD untuk mengetahui kelompok mana yang berbeda secara signifikan. 
HASIL

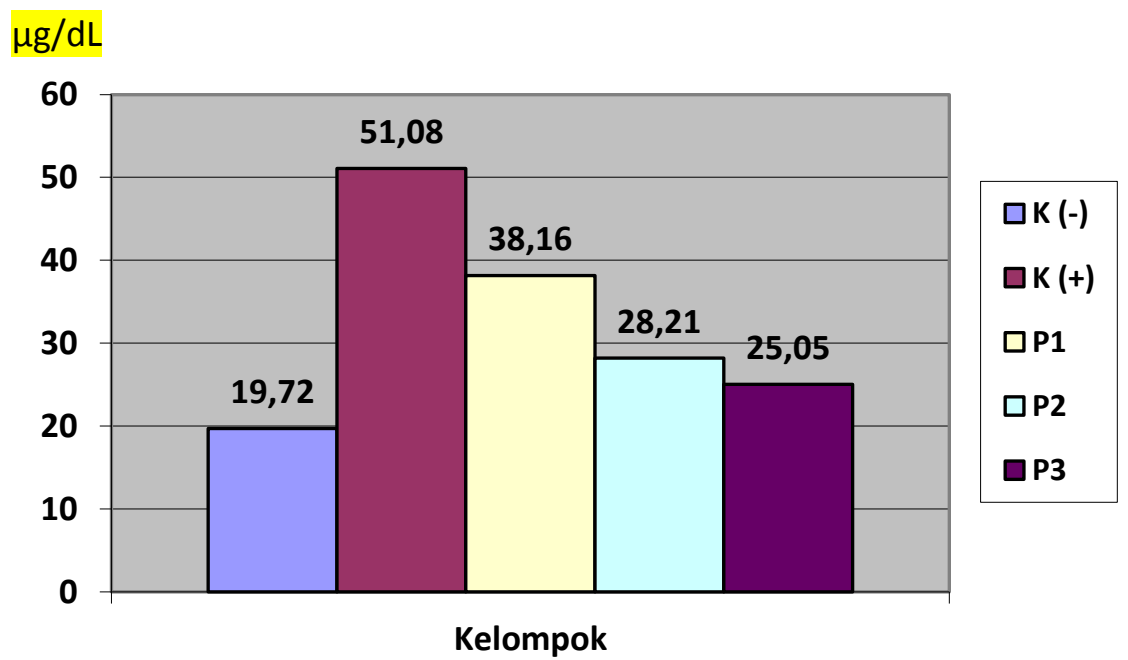

Gambar 1. Kadar ureum darah tikus pada kelompok kontrol dan perlakuan

Keterangan: Kontrol negatif $\mathrm{K}(-)$; Kontrol positif $\mathrm{K}(+)$ diberi $\mathrm{CCl}_{4} \quad 0,36 \mathrm{ml} / 136 \mathrm{gBB} / 3$ hari; P1 diberi ekstrak mawar merah $1,25 \mathrm{mg}+\mathrm{CCl}_{4} \quad 0,36 \mathrm{ml} / 136 \mathrm{gBB} / 3$ hari; $\mathrm{P} 2$ diberi ekstrak mawar merah 2,5 mg + CCl 40,36 $\mathrm{ml} / 136 \mathrm{gBB} / 3$ hari; $\mathrm{P} 3$ diberi ekstrak mawar merah $5 \mathrm{mg}+\mathrm{CCl}_{4}$ 0,36 ml/136 gBB/3 hari.

Hasil penelitian menunjukkan bahwa kadar ureum antar kelompok perlakuan berbeda antara satu dengan lainnya. Kadar normal ureum darah adalah $10-50 \mathrm{mg} / \mathrm{dL}$, hal ini sesuai dengan kelompok kontrol negatif yang menunjukkan rata-rata kadar ureum sebesar $19,72 \mathrm{mg} / \mathrm{dL}$. Sementara pada kelompok kontrol positif, setelah diinduksi oleh $\mathrm{CCl}_{4}$ dengan dosis 0,18 $\mathrm{ml} / 136 \mathrm{gBB} / 3$ hari, kadar ureum meningkat menjadi $51,08 \mathrm{mg} / \mathrm{dL}$.

Pada kelompok P1, P2, dan P3, pemberian tablet effervescentmawar merah menunjukkan peranan yang berarti dalam menurunkan kadar ureum darah tikus putih galur Wistar. Kelompok P1 dengan dosis tablet effervescentmawar merah $1,25 \mathrm{~g} / \mathrm{hr}$ memberikan kadar ureum rata-rata sebesar $39,16 \mathrm{mg} / \mathrm{dL}$. Namun, pada P2, pemberian dosis tablet effervescentmawar merah sebesar 2,5 g/hr menunjukkan kadar ureum yang makin menurun, yaitu $28,21 \mathrm{mg} / \mathrm{dL}$, dan pada P3 kadar ureum turun menjadi $25,05 \mathrm{mg} / \mathrm{dL}$ pada dosis tablet effervescentmawar merah sebesar $5 \mathrm{~g} / \mathrm{hr}$.
Jadi disimpulkan bahwa pemberian tablet effervescent mawar merah dapat mempengaruhi (menurunkan) kadar ureum darah tikus putih galur Wistar.

\section{PEMBAHASAN}

Ureum adalah produk akhir utama katabolisme protein yang harus dikeluarkan dari tubuh untuk memastikan kelangsungan metabolisme protein dalam sel. ${ }^{2}$ Biosintesis urea terjadi dalam empat tahap: (1) Transaminasi yang mengonversi hampir semua asam amino protein dan membentuk glutamat, (2) glutamat mengubah nitrogen a-amino menjadi amonia yang disebut transdeaminasi. (3) L-amino oksidase di hati dan ginjal mengalami dekomposisi menjadi asam a-keto disertai pembebasan ion amonium. (4) dan terjadi reaksi siklus urea dan menghasilkan produk akhir berupa ureum. ${ }^{10}$ Konsentrasi ureum dalat meningkat sampai 10 kali normal selama satu sampai dua minggu pada orang gagal ginjal. Dengan alasan ini, pengukuran konsentrasi ureum 
merupakan cara yang penting untuk menilai fungsi ginjal. ${ }^{2}$

Berbagai macam bahan kimia yang berasal dari lingkungan dan bahan kimia yang dapat digunakan untuk pengobatan, seperti asetaminofen dan gentamisin, dapat menyebabkan kerusakan organ tubuh melalui aktivasi metabolik sehingga menghasilkan radikal bebas termasuk superoksida dan ROS.11 Salah satu bahan kimia yang banyak digunakan untuk penelitian adalah $\mathrm{CCl}_{4}$ yaitu suatu pelarut yang sering digunakan dalam industri dan dapat menginduksi berbagai macam kerusakan organ, termasuk ginjal.

Penelitian secara in vitro dan in vivo menunjukkan bahwa $\mathrm{CCl}_{4}$ mempercepat peroksidasi lipid, mengurangi sitokrom P450 NADPH, dan mengurangi GHS/GSSG pada kortek ginjal, yaitu pada mikrosom dan mitokondria ginjal. ${ }^{12}$ Pemberian $\mathrm{CCl}_{4}$ secara intraperitoneal akan terdistribusi dan terdeposit pada berbagai macam organ, seperti hepar, otak, ginjal, paru-paru, dan jantung. ${ }^{13}$ Pada penelitian ini, kerusakan organ akan difokuskan pada organ ginjal dengan parameter berupa peningkatan kadar kreatinin darah tikus.

$\mathrm{CCl}_{4}$ secara aktif dimetabolisme oleh jaringan tubuh sehingga menghasilkan reaktif metabolit terhalogenasi $\left(. \mathrm{CCl}_{3}\right.$ dan .Cl) dan metabolit tersebut menimbulkan serangkaian reaksi yang melepaskan ROS yang termasuk dalam radikal bebas. ${ }^{14} \mathrm{CCl}_{3}{ }^{-}$ memiliki molekul derivatif yang juga sangat reaktif, yaitu radikal trichloromethylperoxyl $\left(\mathrm{Cl}_{3} \mathrm{COO}\right)$ yang dapat menyebabkan induksi peroksidasi lipid. ${ }^{15-17}$ Radikal bebas tersebut mampu menginisiasi serangkaian reaksi peroksidasi lipid dengan menghilangkan hydrogen dari PUFA. Hilangnya hydrogen dari PUFA yang merupakan struktur pembentuk membran sel menyebabkan perubahan pada membran sel sehingga kerusakan sel tidak dapat dihindari. Hal ini merupakan mekanisme penting dalam patogenesis yang mendasari timbulnya berbagai penyakit yang disebabkan oleh radikal bebas. ${ }^{15}$

Penelitian Tom et al menunjukkan bahwa hal tersebut melibatkan berbagai sistem reaksi enzimatik dan non-enzimatik. ${ }^{18}$ Ketika tubuh menerima radikal bebas yang berlebihan, sistem pertahanan tubuh tidak cukup untuk menetralisir radikal bebas tersebut. Selain itu, ROS juga dapat menurunkan sistem antioksidan tubuh alami seperti GSH dan juga menurunkan aktivitas dari SOD, CAT, dan GSH-Px. ${ }^{19}$

Parameter yang diamati pada penelitian ini adalah kadar ureum darah tikus putih setelah diberikan tablet effervescentekstrakmawar merah yang memengaruhi fungsi organ ginjal. Hal ini didasarkan prinsip bahwa ureum merupakan produk sisa yang diekskresikan oleh ginjal terutama melalui filtrasi glomerulus.

Ureum merupakan metabolit protein akhir yang dapat ditemui dalam plasma darah. Urea direabsorbsi ke darah dengan cara difusi. Molekul urea sangat kecil sehingga bisa menembus membran dengan cara difusi lipid. Proses ini adalah proses pasif sehingga urea terdifusi ke darah sampai gradien konsentrasi urea pada filtrat dan darah sama. Karena itulah sebagian urea melewati ginjal dan keluar melalui urin, sedangkan sebagian lagi tetap berada di darah dan bisa dihitung kadarnya.

Percobaan yang dilakukan Ruqiah et al (2007) menyebutkan bahwa pemberian $\mathrm{CCl}_{4}$ $0,1 \mathrm{ml} / \mathrm{kg}$ BB dan $1 \mathrm{ml} / \mathrm{kg}$ BB mengakibatkan peningkatan kadar kreatinin, masing-masing $52,12 \mathrm{mg} / \mathrm{dL}$ dan $84,47 \mathrm{mg} / \mathrm{dL}^{20}$ Peningkatan kreatinin ini mungkin berkaitan dengan terjadinya kerusakan sel hati yang disebabkan oleh $\mathrm{CCl}_{4}$.

Antosianin merupakan pigmen yang larut dalam air dan tergolong ke dalam senyawa flavonoid. ${ }^{21}$ Pigmen antosianin adalah pewarna alami kelompok flavonoid yang tergolong jenis polifenol, penyebab 
warna merah, oranye, ungu dan biru, banyak terdapat pada bunga dan buah-buahan (seperti bunga mawar, pacar air, kembang sepatu, krisan, pelargonium, aster cina, dan buah apel, chery, anggur, strawberi). ${ }^{22}$ Kurangnya elektron natural pada antosianin membuat komponen ini reaktif terhadap radikal bebas. Antosianin merupakan antioksidan yang poten karena kemampuannya yang secara cepat untuk mereduksi spesies oksigen dan merubahnya menjadi radikal aryloxyl yang lebih stabil. ${ }^{23,24}$ Pada kenyataannya, penelitian menunjukkan bahwa antosianin dapat memiliki aktivitas antioksidan yang lebih tinggi daripada vitamin $E$, asam askorbat, dan beta karoten. ${ }^{25,26}$

Penelitian yang dilakukan oleh Lin-Hua et al (2010), menyatakan bahwa ekstrak antosianin dari buah blueberry dapat secara langsung meredakan gejala kolitis pada tikus. Dosis antosianin yang diberikan pada penelitian ini adalah 10, 20 dan 40/mg/kg per hari selama 6 hari. Semua dosis tersebut dapat mencegah diare sehingga mengurangi penurunan berat badan dan kematian pada hewan coba. Secara histologis dan makroskopis juga menunjukkan bahwa pemberian ekstrak antosianin blueberry per oral dapat meredakan inflamasi usus. ${ }^{27}$

Pada kondisi fisiologis normal, pemberian ekstrak antosianin per oral secara signifikan $(p<0,05)$ meningkatkan kapasitas absorbansi radikal bebas dari serum deproteinasi sekitar $50 \%$ setelah 10 hari pemberian ekstrak antosianin. ${ }^{28}$ Kadar antosianin dalam plasma segera meningkat setelah pemberian ekstrak antosianin per oral. ${ }^{28-31}$ Oleh karena itu, terjadi peningkatan aktivitas antioksidan sejalan dengan peningkatan kadar antosianin plasma.

Pada penelitian ini, antosianin diberikan dalam bentuk tablet effervescent ekstrak mawar merah. Tablet effervescent yaitu tablet yang dimaksudkan untuk menghasilkan larutan secara cepat dengan menghasilkan $\mathrm{CO}_{2}$ secara serentak. Tablet khususnya dibuat dengan cara pengempaan bahan-bahan aktif dengan campuran asamasam organik, seperti asam sitrat dengan sodium bikarbonat. ${ }^{32}$ Penggunaan mawar merah didasarkan atas penelitian Saati pada tahun 2011 yang membandingkan kandungan antosianin pada mawar merah dengan bunga kana dan pacar air. Hasil penelitian tersebut didapatkan bahwa kandungan tertinggi antosianin terdapat pada bunga mawar, yaitu sebesar 19,43 $\mathrm{mg} / 100 \mathrm{ml} / 35 \mathrm{~g}$ kelopak bunga. Pemilihan bentuk sebagai tablet effervescent adalah berdasarkan dari penggunaannya yang praktis dan lebih menarik. Namun demikian, kandungan antosianin dalam bentuk tablet effervescent akan menurun dibandingkan dengan pigmen pekat dan bubuk pigmen. Penurunan daya antioksidan pada tablet effervescent sebesar $78,25 \%{ }^{33}$

Sesuai dengan hasil penelitian ini, didapatkan bahwa tablet effervescent mawar merah.

\section{KESIMPULAN}

1. $\mathrm{CCl}_{4}$ merupakan zat yang menyebabkan kerusakan ginjal yang ditandai dengan peningkatan kadar ureum darah tikus putih galur Wistar (Rattus norvegicus).

2. Pemberian tablet effervescent mawar merah mampu menurunkan kadar ureum darah tikus putih galur Wistar (Rattus norvegicus) yang telah diinduksi oleh $\mathrm{CCl}_{4}$.

3. Dosis tablet effervescent mawar merah yang menunjukkan pengaruh secara signifikan adalah sebesar $5 \mathrm{~g}$.

\section{SARAN}

1. Perlu adanya penelitian lebih lanjut mengenai indikator kerusakan ginjal yang lain seperti TGF-ß1, TBARS, MDA ginjal, 
penurunan kadar GSH, SOD, GR, GPX dan GST.

2. Perlu adanya penelitian lebih lanjut tentang efek pemberian tablet effervescent mawar merah pada manusia.

\section{DAFTAR PUSTAKA}

1. Purnomo BB. Dasar-Dasar Urologi. Jakarta: CV. Sagung Seto. 2000.

2. Guyton AC,John EH. Buku Ajar Fisiologi Kedokteran. Irawati dkk (Penerjemah). Rachman LY dkk (Editor). Edisi ke-11. Jakarta: EGC.2007.

3. Setiati S. Radikal Bebas, Antioksidan dan Proses Menua.Majalah Medika. 2003; 6(19):366-368.

4. Kim HJ, Odendhal S, Bruckner JV. Effect of Oral Dosing Vehicles on the Acute Hepatotoxicity of Carbon Tetrachloride in Rats. Toxicol Appl Pharmacol.1990; 102:34-49.

5. Halliwell B. The Biological Toxicity of Free Radicals and Other Reactive Oxygen Species. In: Free Radicals and Food Additives. Aruoma OI, Halliwell B, Taylor \& Francis (Editor). London, New York, Philadelphia. 1991:41-45.

6. Poli G, Albano E, Dianzani MU. The Role of Lipid Peroxidation in Liver Damage. Chem Physiol Lipids. 1987;45(2-4):117-42.

7. Rungby J, Ernst E. Experimentally Induced Lipid Peroxidation after Exposure to Chromium, Mercury or Silver: Interactions With Carbon Tetrachloride. Pharmacol Toxicol. 1992:70(3):205-207.

8. Adewole SO, et al. Effect of Melatonin on Carbon Tetrachloride-Induced Kidney Injury in Wistar Rats. African Journal of Biomedical Research. 2007; 10:153-164.

9. Saati ES, Mujianto, Susestyarini RE. Optimalisasi Fungsi Ekstrak Pigmen
Bunga Kana (Canna sp.) sebagai Zat Pewarna dan Antioksidan Alami Melalui Isolasi dan Karakterisasi. Laporan Fundamental Research (Tahun I-II). DP3M-DIKTI DIKNAS. Jakarta.2006.

10. Murray RK, Daryl KG, Victor WR. Biokimia Harper. Jakarta: EGC.2009.

11. Abraham P, Wilfred $G$, Cathrine SP. Oxidative Damage to the Lipids and Proteins of the Lungs, Testis and Kidney of Rats during Carbon Tetrachloride Intoxication. Clin Chim Acta. 1999;289(1-2):177-9.

12. Walker G, Kunz D, Pignat W, Wiesenberg I, Van den Bosch $\mathrm{H}$, Pfeilschifter J. Tetranactin Inhibits Interleukin-1 $\beta$ and cAMP Induction of Group II Phospholipase A2 in Rat Renal Messangial Cells. Eur J Pharmacol. 1996; 306(3):265-270.

13. Ko KM, Ip SP, Poon MK, Wu SS, Che $\mathrm{CT}, \mathrm{Ng} \mathrm{KH}$, Kong YC. Effect of A Ligninenriched Fructus schisandrae Extract on Hepatic Glutathione Status in Rats: Protection against Carbon Tetrachloride Toxicity. Planta Med. 1995;,61:134-137.

14. Slater TF. Free Radical Mechanism in Tissue Injury. Biochemistry Journal.1984; 222:1-15.

15. Aleynik SI, Leo MA, Ma X, Aleynik MK, Lieber CS. Polyenylphosphatidycholine Prevents Carbon Tetrachloride-Induced Lipid Peroxidation While It Attenuates Liver Fibrosis. J Hepatol. 1997;27: 554561.

16. Charbonneau M, Brodeur J, Du Souich P, Plaa GL. Correlation between Acetone-Potentiated CCl4-Induced Liver Injury and Blood Concentrations after Inhalation or Oral Administration. Toxicology and Applied Pharmacology. 1986; 84:286-294.

17. Ozturk F, Ucar M, Ozturk IC, Vardi N, Batcioglu K. Carbon Tetrachlorideinduced Nephrotoxicity and 
Protective Effect of Betaine in SpragueDawley Rats. Urology. 2003; 62:353356.

18. Tom WM, Fong D, Woo B, Prasongwatana V, Boyde TR. Microsomal Lipid Peroxidation and Oxidative Metabolism in Rat Liver. Chemical and Biological Interactions. 1984; 50:361-363. doi: 10.1016/00092797(84)90043-7Tom WM.

19. Yamamoto Y, Yamashita S. Plasma Ubiquinone to Ubiquinol Ratio in Patients with Hepatitis, Cirrhosis, and Hepatoma, and in Patients Treated with Percutaneous Transluminal Coronary Reperfusion. BioFactors.1999; 9:241145.

20. Panjaitan RGP, HaryaniE, Chairul, Masriani, Zakiah Z, Manalu W. Makara Kesehatan. 2007; 11(1):11-16.

21. Saati EA. Pigmen sebagai Zat Pewarna dan Antioksidan Alami. Malang: UMM Press.2008.

22. Lewis RJ. Hawley's Condensed Chemical Dictionary. 22 ${ }^{\text {th }}$ Edition. New York: Van Nostrand Reihold Company. 1993.

23. Khkonen MP, Heinonen M. Antioxidant Activity of Anthocyanins and their Aaglycons. J Agric Food Chem.2003; 51:628-633.

24. Moran JF, Klucas RV, Grayer RJ, Abian $\mathrm{J}$, Becana M. Complexes of Iron with Phenolic Compounds from Soybean Nodules and Other Legume Tissues: Prooxidant and Antioxidant Properties.Free Radic Biol Med.1997; 22:861-870.

25. Galvano F, La Fauci L, Lazzarino G, Fogliano V, Ritieni A, Ciappellano S, Battistini NC, Tavazzi B, Galvano G. J Nutr Biochem. 2004; 15:2.

26. Kowalczyk $E$, Krzesiński $P$, Kura $M$, Szmigiel B, Blaszczyk J. Antthocyanins in Medicine. Pol J Pharmacol. 2003; 55:699.
27. Lin-Hua Wu et al. Protective Effect of Anthocyanins Extract from Blueberry on TNBS-Induced IBD Model of Mice. Evidance-Based Complementary and Alternative Medicine.2010; (2011). Article ID 525462.

28. Lionetto et al. Effect of the Daily Ingestion of a Purified Anthocyanin Extract from GrapeSkin on Rat Serum Antioxidant Capacity. Physiol Res. 2011; 60:637-645.

29. Bub A, Watzl B, Heeb D, Rechkemmer G, Briviba K.Malvidin-3-Glucoside Bioavailability in Humans after Ingestion of Red Wine, Dealcoholized Red Wine and Red Grape Juice. Eur J Nutr. 2001; 40:113-120.

30. Mazza G, Kay CD, Cottrell T, Holub BJ. Absorption of Anthocyanins from Blueberries and Serum Antioxidant Status in Human Subjects. J Agric Food Chem. 2002; 50:7731-7737.

31. Wu X, Cao G, Prior Rl. Absorption and Metabolism of Anthocyanins in Human Subjects Following Consumption of Elderberry or Blueberry. J Nutr.2002; 132:1865-1871.

32. Mustofa Z. Pembuatan Tablet Effervescent dari Ekstrak Mawar Merah (Rosa sp.): Kajian Varietas Bunga, Jenis Pelarut dan Jenis Gula. Skripsi. Malang: Jurusan IImu dan Teknologi Pangan, UMM.2008.

33. Saati ES, Sukardi, Zainab S. Formulasi Tablet Effervescent Kaya Antioksidan dari Ekstrak Pigmen Tiga Varietas Bunga Mawar Merah (Rosa sp.). Hibah bersaing DIKTI. 2011. 